\title{
Water Harvesting and Soil Water Retention Practices for Forage Production in Degraded Areas in Arid Lands of Mexico
}

\author{
Aurelio Pedroza-Sandoval, Ricardo Trejo-Calzada, \\ Ignacio Sánchez-Cohen, Luis G. Yáñez-Chávez, \\ Adriana Cruz-Martínez and \\ Uriel Figueroa-Viramontes
}

Additional information is available at the end of the chapter

http://dx.doi.org/10.5772/intechopen.69618

\begin{abstract}
The area under arid conditions in Mexico is greater than $50 \%$. This area faces a high risk due to environmental effects. The soil degradation in arid, semi-arid, and dry sub-humid areas is of multi-causal nature, among which climatic and anthropogenic factors stand out. At least, three distinct elements with different effects may be considered: recurrent droughts in short periods, long-term climate fluctuations, and degradation of soils by human activities. These threaten the productivity and sustainability of ecosystems and agro-ecosystems. Thus, it is needed to maintain a constant exploration of new and more appropriate technologies that promote the efficient use of natural resources, in a framework of greater sustainability. Many of these technologies are focused toward better management of water and soil resources in production systems. Water management is oriented with rainwater harvesting, efficient irrigation systems, as well as soil moisture retention techniques, and the use of plant species tolerant to water stress. Planting of native species and using soil improvers of edaphic moisture retention can enhance reclamation (recovery) of degraded soils. The aim of this chapter is to show and discuss some experimental results using the above technologies applied to rangelands with degraded soils in dry lands.
\end{abstract}

Keywords: soil degradation, dry lands, grasses, productive reconversion, soil water content

\section{Introduction}

Current world population exceeds 7200 million people and it is expected to reach 9.6 billion in 2050 [1]. The population growth is greatest in developing countries, with the consequent 
increase in pressure on the use of natural resources, in response to food demand and other services. Arid zones are among the top issues due to their territorial extension and the abundance and diversity of their natural resources. These regions represent one of the most viable options to respond to the challenges of the twenty-first century. However, there is a need for a systemic and comprehensive vision of the potential limitations that exist in these areas, which involves identification of current and future conditions on the state of natural resources, as a basis for the design and implementation of development plans. Globally, one of the challenges in this century is to reduce poverty in developing countries. One possibility to reach this goal is through a better management of natural resources involved in food production, such as water and soil, as well as the conservation of biodiversity, and the restoration of fragile ecosystems from the arid zones.

The socio-ecological systems in arid lands cover approximately $45 \%$ of the planet's surface, where about 2 billion people live, accounting for $33.8 \%$ of the world population [2-4]. In these regions, a critical situation is the depression of the local economies because of the impacts of the drought on economic activities and the natural resources, mainly water, soil, and native plants and animals, expressed in processes of desertification. These processes are expanding and Mexico will be one among the most affected countries. Thus, it is predicted that in 2050, rainfall and irrigated maize production will be reduced by 17 and $8 \%$, respectively; while wheat production under rainfall systems could be reduced by $19 \%$ and in systems under irrigation by $8 \%$ [5].

The Mexican desert covers more than $50 \%$ of the national surface, which has different degrees of aridity typified by the characteristics of rainfall [6]. In this area, around $18 \%$ of the national population is located [7]. Moreover, the larger water demands are in the north and center of the country, which becomes a problem, since Mexico presents a territorial contrast of shortage and abundance of water [8]; while in southern Mexico frequent floods occur, in Northern Mexico, rainfall is very irregular and scarce. Then, the country is divided into two large areas: (1) Northern, central and northeast, where $77 \%$ of the population is concentrated, and $80 \%$ of gross domestic product (GDP) is generated in this region, but only $31 \%$ is renewable water. (2) Southern and southeast, where $23 \%$ of the population lives there, and only $20 \%$ of GDP is generated, but in this place, occurs $69 \%$ of renewable water [9].

\section{Zoning for the best use of natural resources}

A proper use of the natural resources in a region may be reached by a micro-regionalization, which allows one to know the amount of small areas that integrate any zone with natural similarities within each micro-region.

\subsection{Agroecological zoning by geographical information system (AEZ/SIG)}

The agroecological zoning is a methodology aimed at the evaluation of soil resources that integrates the use of geographic information systems. It has been applied in several countries and has been adopted as the method of evaluation of soil resources. This methodology is used 
in a holistic focus in territorial planning projects, and is a tool proposed by the AEZ methodology combined with the geographical information systems [10].

The development of cartographic procedures to obtain agroecological zoning is a current issue related to the concept of sustainability. These tools present the spatial classification of a territory per its potential capabilities, such as: production and protection zones, zone restoration, and identification of optimal areas for the intensive development of commercial plantations, among other uses. Thus, the decision takers may design plans to make better use and management of natural resources, such as biotic resource to increase profits, but also to improve and increase the existing natural capital over time.

AEZ/SIG methodology separates areas based on combinations of soil, physiography, and climate. This tool has several applications for land characteristics and types of uses such as potential land productivity, risk assessment of degradation, environmental impact assessment estimation of arable land, among others [11]. Most AEZ/SIG studies identify the types of land use (TLU) regarding crops or range of crops and input levels [12].

\subsection{Case of study of zoning in arid lands}

The middle watershed Nazas-Aguanaval region of the country is an area of the Chihuahuan desert, where ecosystems and agro-ecosystems with environmental, economical, and social importance are located. Beyond regionalization somewhat generic, the middle watershed Nazas-Aguanaval does not have a project of specific regionalization, based on an integrative approach from the physical and biological point of view, to allow better planning of natural resources directly related to regional development processes. This is important, given the need for greater agricultural production and, at the same time, to make more rational use of resources with minimal or no adverse environmental impacts. In this case of study [13], different indicators were used to make the comprehensive characterization of a region, considering both physical factors and the most important biological factor [14]. Aridity index, index of seasonal drought, vegetation, and type of soil were the indicators used for the survey of regionalization. Steps of study: (1) The middle watershed Nazas-Aguanaval map was generated with digital sub-watersheds [15] and the boundaries that are defined between the Francisco Zarco and Lázaro Cárdenas dams, shunt, and storage of RH 36, respectively (Figure 1A); (2) From the National Weather Service, we obtained the climatic stations for the middle watershed Nazas-Aguanaval of the states of Durango and Zacatecas, Mexico, which were geo-referenced (Figure 1B); (3) Applying the program [16] and the INEGI data base [15], the physiographic (vegetation and soil) characteristics of the middle watershed Nazas-Aguanaval were identified, using the digital information from the native vegetation and soil scale 1:250,000 (Figure 2A and B); (4) Interpolation was performed by the inverse distance weighted (IDW) method with the ArcMapTM 10.1 software to obtain the drought and aridity index using a raster graphics.

The different micro-regions were identified based on the degree of aridity. We used the Emberger aridity index modified by Stretta and Mosiño [17], which integrates the predominant action of the rainfall regime and the influence of the maximum and minimum average temperatures of the hottest and coldest, respectively. For the calculation of the aridity condition, the series of historical climatological data (1979-2008 of the National Meteorological Service) of 26 climatic stations in the study area was used (Figure 3A). 

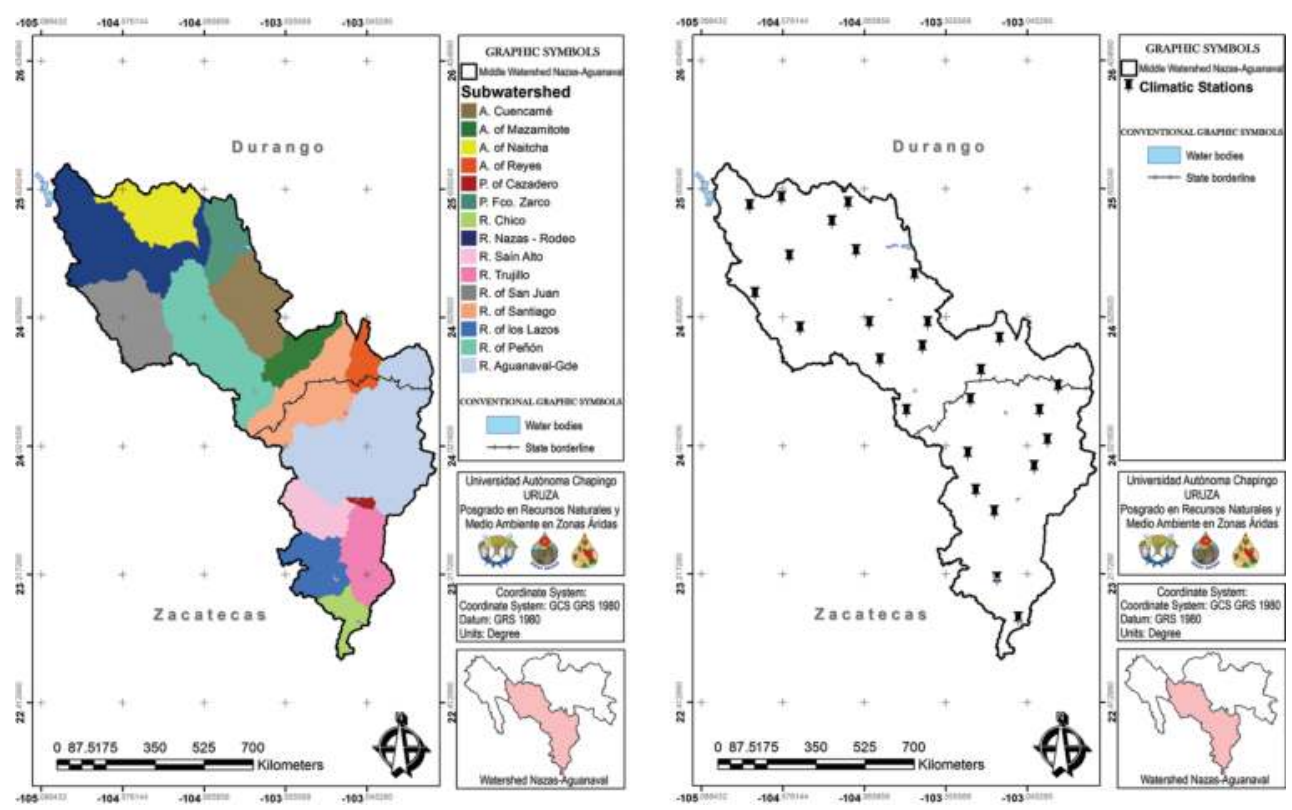

Figure 1. Middle watershed Nazas-Aguanaval and sub-watersheds (A) geo-referencing climatic stations, marked with black dots (B) (Source: Compiled by author based on maps available at [15]).
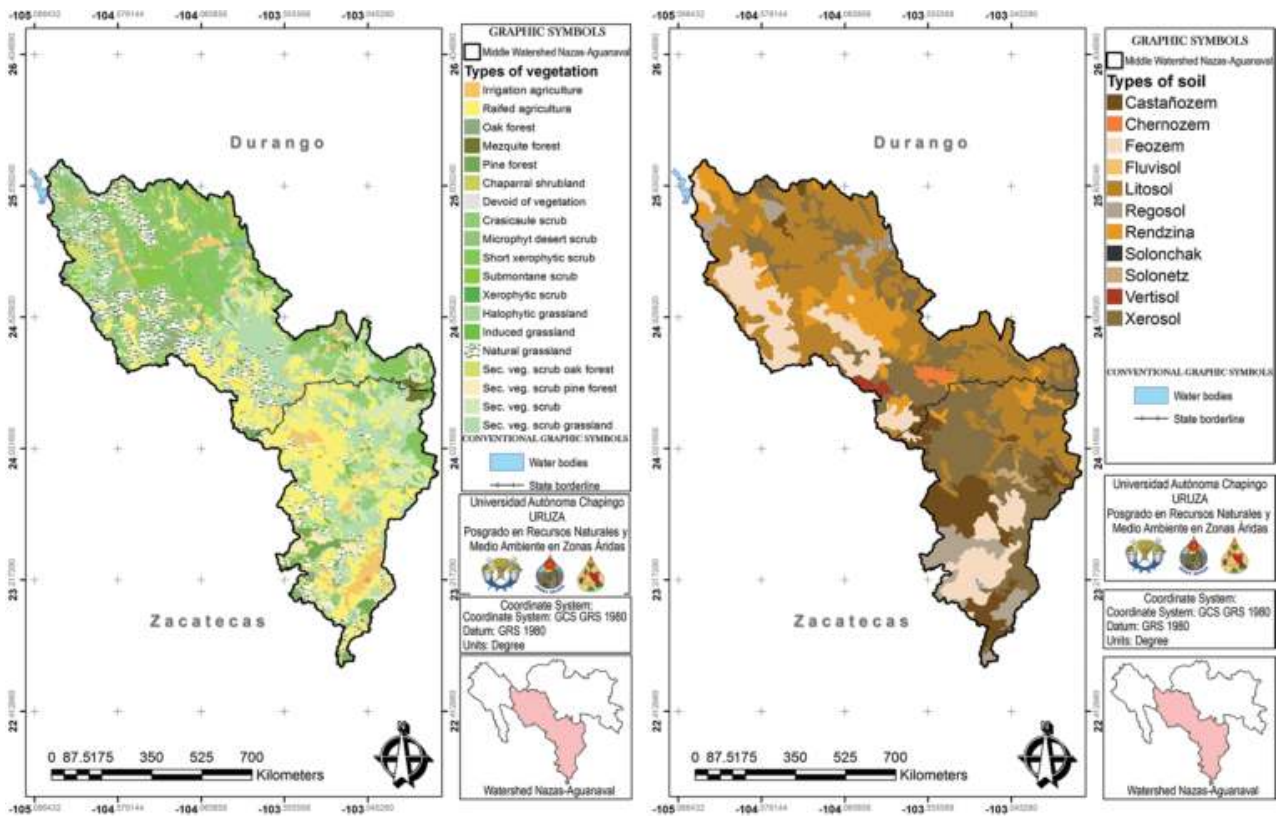

Figure 2. Types of vegetation (A) and types of soil (B) in the middle watershed Nazas-Aguanaval (Source: Compiled by author based on maps available at [15]). 

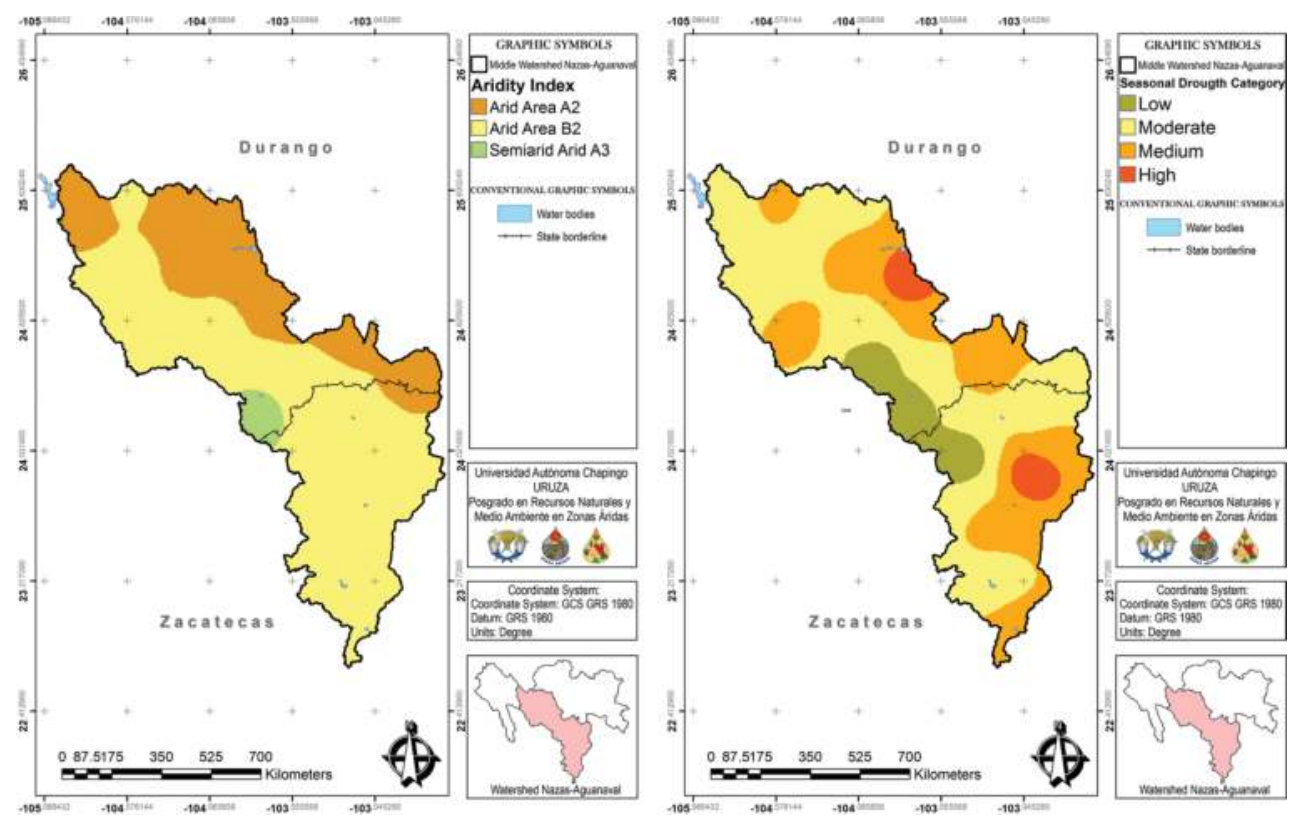

Figure 3. Levels of aridity (A) and spatial distribution of seasonal drought in the middle watershed Nazas-Aguanaval (B). (Source: Compiled by authors).

Annual drought regionalization and its intensity were calculated through the water precipitation information, which was collected from the 26 climactic stations with complete data for every year [18]. The number of years with drought was recorded for the selected seasons. A scale in percentage of years in the presence of drought was established to categorize the levels (Figure 3B).

The categorization proposed by integrating the indicators mentioned above arises from the possible combinations of the different levels of each regionalization approach, resulting in the following micro-regions:

Micro-region 1: corresponding to the most arid place of the aridity index type $A_{2}$, with predominant halophytic grassland vegetation and moderate seasonal drought. Micro-region 2: is the most arid place of the aridity index type $B_{2}$, with natural grassland having a seasonal medium drought. Micro-region 3: corresponding to less arid of the aridity index $A_{2}$, with microphyll desert scrubland but with a moderate seasonal drought. Micro-region 4: also corresponding to less aridity index $\mathrm{A}_{2}$, but with predominant halophytic grassland vegetation and rainfall agriculture, and moderate seasonal drought. Micro-region 5: also corresponds to most aridity index $A_{2}$, but with xeric scrubland as main vegetation and short xerophytic scrub as secondary vegetation, but with a medium seasonal drought. Microregion 6: corresponding to aridity index $A_{2}$, like the previous micro-regions, but here the predominant native vegetation is microphyll desert scrubland and xeric scrubland as secondary vegetation, and has a high seasonal drought. Micro-region 7: with aridity index $\mathrm{B}_{2^{\prime}}$ with natural grassland as vegetation primary and chaparral scrubland as secondary vegetation and medium seasonal drought. Micro-region 8: also with aridity index $\mathrm{B}_{2^{\prime}}$ but 
with xeric scrubland as main vegetation and natural grassland as secondary vegetation, but with a moderate seasonal drought. Micro-region 9: with the same aridity index $\mathrm{B}_{2^{\prime}}$ but here the natural grassland as the main vegetation and rainfall agriculture and a low seasonal drought. Micro-region 10: with aridity index $\mathrm{A}_{2^{\prime}}$ but with halophytic grassland as main vegetation and xeric scrubland as secondary vegetation, but with a medium seasonal drought. Micro-region 11: also aridity index $B_{2}$, but predominantly crassicaule scrubland vegetation and a medium seasonal drought. Micro-region 12: with aridity index $\mathrm{A}_{3^{\prime}}$ corresponding to less arid place from the semiarid areas, with rainfall agriculture as main vegetation and pine forest as secondary vegetation, but with a low seasonal drought. Micro-region 13: aridity index $\mathrm{A}_{2}$ with xeric scrubland having a moderate seasonal drought. Micro-region 14: corresponding to aridity index $\mathrm{B}_{2}$, but predominantly natural grassland vegetation and a

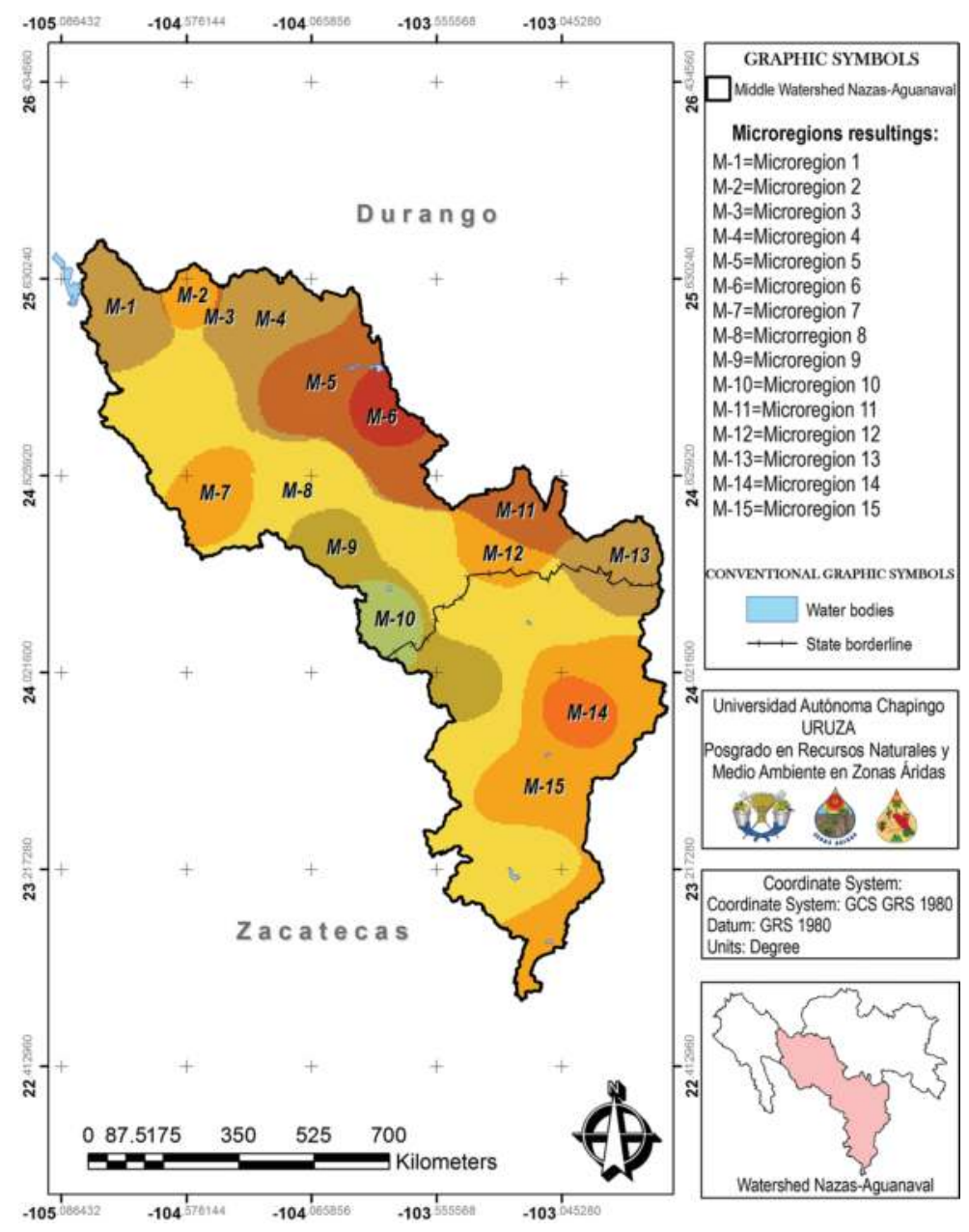

Figure 4. Micro-regions resulting in the central-north region of Durango by type of vegetation and soil, degree of aridity and intensity of temporary drought (Source: Compiled by authors). 
high seasonal drought. Micro-region 15: aridity index $B_{2}$ with rainfall agriculture having a medium seasonal drought (Figure 3).

The identification of the 15 micro-regions of the study area, should allow planning a more targeted and systematic use of natural resources, based on the biophysical characteristics. A planning process with different purposes, such as: conservation, development and/or production of biotic resources in arid zones. According to different authors [19-21], regionalization is the best planning tool, especially when integrating different biophysical indicators such as the type of soil, type of native vegetation, frequency of droughts and aridity conditions (Figure 4).

\section{Water harvesting and soil water conservation practices in arid lands for forage production}

Through soils with low productive capacity and crops with high resistance to water stress could be possible to define areas for productive reconversion. The criteria include water harvesting and the use of some humidity retainers to increase the water holding capacity of the soil. Of this way is possible to promote the gradual recovery of the soil cover reducing soil and wind erosion, which are the main problems related to soil productivity in arid lands.

\subsection{Degradation of soil in arid zones as the problem to mitigate}

Desertification occurs because of the degradation of natural ecosystems in dry lands, which is a big global problem. Soil degradation causes may be included into three broad aspects: (a) physical, where climate plays a big role in terms of floods, droughts that enhance soil erosion; (b) chemical, generally in the form of salinization; and (c) biological, mainly as a result of the oxidation of the organic matter of the soil [22].

The main consequences of land degradation are chemical degradation of the soil, related to soil chemical contamination with several toxic elements like heavy metals and salts, which makes loss of vegetative cover, loss of soil surface layer infiltration, reduction of water storage in the soil, loss of soil organic matter, fertility and structure, loss of soil elasticity, loss of natural regeneration, and decrease of water level. Degradation affects most of the arid zones, mainly in marginal cultivated areas [11].

Most of the world's dry lands are degraded. In Mexico, estimates of the magnitude of degradation may differ from the methods used to calculate them. Even though, there are not specific studies on the extent of desertification in Mexico, the approach of this chapter considers soil degradation as an estimator of desertification recognizing the limitation, since only one considers its elements. On the other hand, the information included data back to 10 years [23].

\subsection{Decision-making natural resource management}

Before making any practices for planting native vegetation species that rehabilitate degraded soils in arid zones, are necessary to select wisely the species to grow. The aim of this part of 
study was to select species that meet the environmental conditions. Once the main problem is identified, the resource management system (RMS) planning tool provides a series of alternatives to cope with those problems. These alternatives were adjusted according the specific conditions encountered in the field [24].

The usefulness of the RMS planning tool is to perform a decision matrix composed by the resource concern and the alternatives. The soil, water, animals, plants atmosphere humans (SWAPAH) serves this purpose after a series of problems have been identified in the field. The tool provides a series of alternatives that are evaluated according to its impact on the resource concern. Therefore, a group of professionals select those alternatives with the less negative impact (or the more positive impact) on the resource. These selected alternatives are then emigrated to a decision support system, which are evaluated according to several criteria imposed by the participants (professionals and those users directly impacted by the decision). For standardizing the scores from 0 to 1 given to the criteria, a scoring function should be selected among: more is better linear, more is better nonlinear, more is worst linear, and desirable range [25, 26]. To facilitate the use of the software, the user is presented with the shapes of these functions from where one should be selected $[25,26]$.

Physical, social, economic, and environmental factors were included in this methodology. The best evaluated practices for their feasibility, viability, and ease of implementation were: grow woody plants (Prosopis spp) and grazing species, particularly buffel grass (Cenchrus ciliaris L.), which is able to adapt to the arid conditions [24].

\section{Recover degraded soil in arid lands: some technologies}

\subsection{Practices for rain water harvesting and soil moisture retention to plant grass}

Drylands are of high ecological vulnerability due to low vegetative cover and erratic and torrential rainfall. The aim of this study was to evaluate the use of different sources and dosages of soil moisture retainers in planting buffel grass (Cenchrus ciliaris L) in a micro-watershed system for harvesting rainwater. Micro-watershed system, are spatial units of different dimensions, since the smallest like $1 \mathrm{~m}^{2}$ or larger dimensions, depending on the specific conditions of the site and based mainly on the hydrological concept of soil division (Figure 5). Additionally, in this survey were used two types of soil water retainers: one chemical product
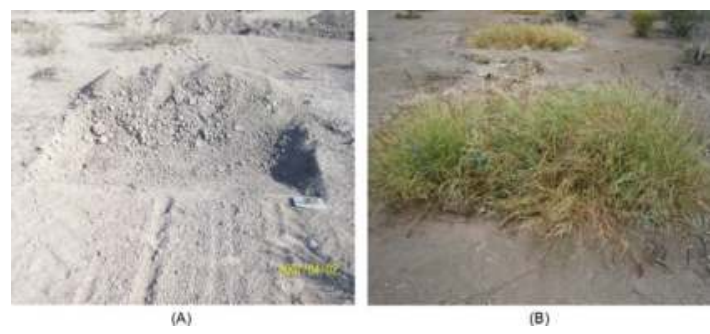

Figure 5. Micro-watershed for water harvesting; when was built (A), and after, when the grass has grown (B). 
named hydrogel, and the other was organic compost. Hydrogel is a polyacrylamide copolymer that, when used in the soil as a substrate, absorbs and retains large amounts of moisture and nutrients, making them available to the plant. In this survey, four dosages of hydrogel were evaluated: $0,5,10$, and $15 \mathrm{~kg} \mathrm{ha}^{-1}$ as well as two compost dosages: 0 and $40 \mathrm{t} \mathrm{ha}^{-1}$ based on dry weight, in the catch system of rainfall water as an experimental unit of $2 \mathrm{~m}^{2}$ each one. The hydrogel and organic compost were incorporated to the soil manually [27].

\subsection{Moisture content in soil}

At 241 days after planting (DAP), the soil moisture content was higher, and then decreased to 346 and $372 \mathrm{DAP}$, with average values of 22.5, 16.8, and 8.2\%, respectively (Figure 6). This trend is related to the rainfall with drought during May and June of the study year, followed by a period, also with relative drought during July and August, but in general this year (2013) was lack of rainfall since the annual average was only $205.4 \mathrm{~mm}$ (Figure 7) [28]. Although the response function showed a negative rate, and showed differences at all three sampling dates, the soil moisture content was always higher when the hydrogel was applied at least for the first two sampling dates (241 and $346 \mathrm{DAP})$, with values on the first date (241 DAP) of 25, 23.2, and $23.4 \%$ when applying 5, 10, and $15 \mathrm{~kg} \mathrm{ha}^{-1}$, respectively, vs $17.5 \%$ when the hydrogel was not applied. A similar pattern was shown in the second sampling date (346 DAP); while at $372 \mathrm{DAP}$, which was not affected by moisture retention, and the different dosages of hydrogel (Figure 8 ). This means that about 157 days after the first sample without a significant rainfall, the effect of soil moisture retention of the hydrogel stopped, arising near the soil wilting point (WP) level. Thus the effect of the hydrogel was identified at least in the first two samples in any dosages included in this study, and the lower dosages of hydrogel (5-10 $\left.\mathrm{kg} \mathrm{ha}^{-1}\right)$ may be used to obtain the same results. Before partially is disagree to [29], who used dosages of $0,20,30$ and $40 \mathrm{~g}$ of hydrogel in $130 \mathrm{~g}$ of sand, the higher dosages of hydrogel showed the best results as retainers of soil moisture [24].

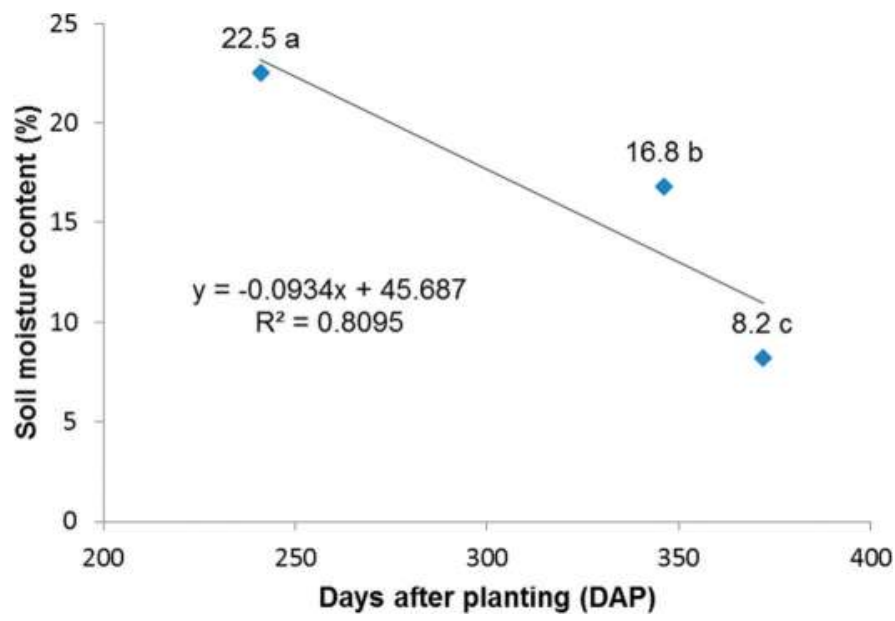

Figure 6. Soil moisture content at different sampling dates in days after planting (DAP) (2013). 


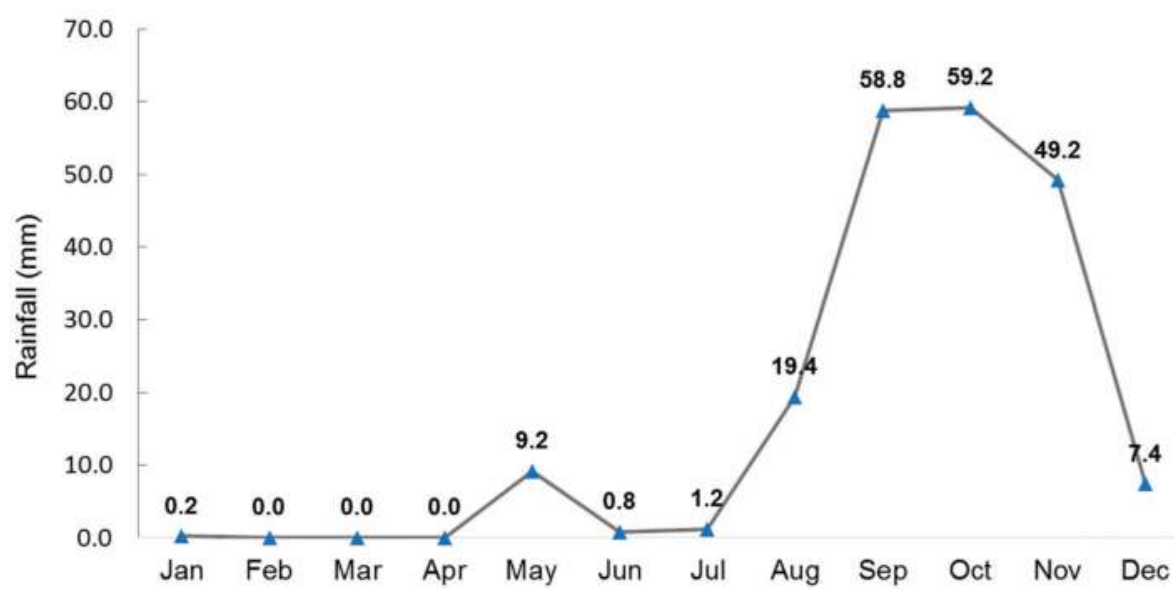

Figure 7. Rainfall during 2013 in the area near to the experimental area to Bermejillo, Dgo, México.

Seedling emergence was $47.7 \%$, when $15 \mathrm{~kg} \mathrm{ha}^{-1}$ of hydrogel was applied, compared to $29 \%$ when it was not applied. The dosages of 5 and $10 \mathrm{~kg} \mathrm{ha}^{-1}$ had intermediate values, with no statistical difference (Figure 9). These results are consistent with those reported by Rojas et al. [30] regarding the use of hydrogel, which had a positive effect on the capacity of germination of tomato (Lycopersicon esculentum Mill).

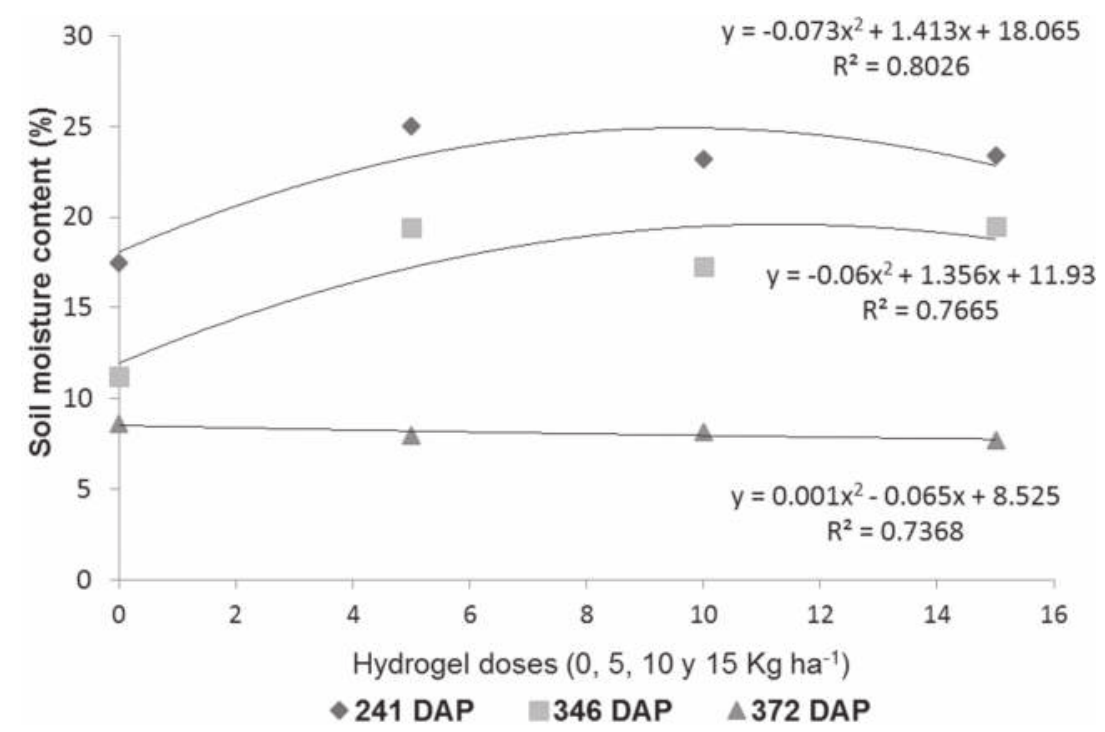

Figure 8. Soil moisture content with different dosages of hydrogel and sampling dates (DAP) (2013). 


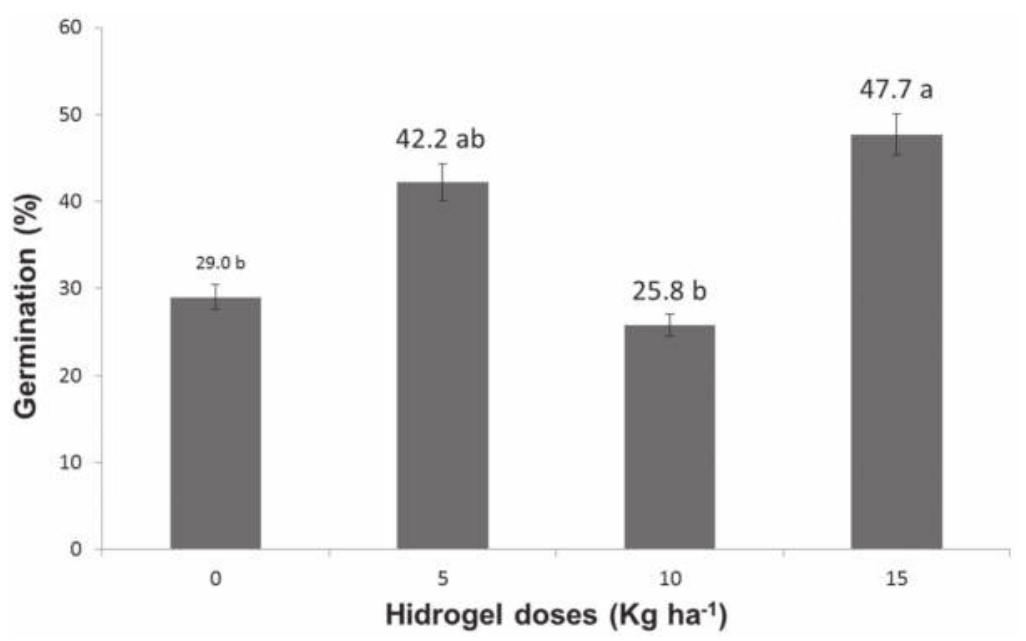

Figure 9. Effect of hydrogel dosages on germination percentage of buffel grass in micro-watershed for water harvesting, during August, 2012.

The lower dosages of hydrogel (5-10 $\left.\mathrm{kg} \mathrm{ha}^{-1}\right)$ used in this study were less effective in seedling emergence, which could mean that at this stage of development of buffel grass, high moisture content is required in the soil, which is expressed to a dose of $15 \mathrm{~kg} \mathrm{ha}^{-1}$. There was no effect on the compost on seed germination of grasses. Even with the low rainfall regime in 2012 and the absence of the treatment effect on the moisture content in the soil, the growth of buffel grass remained constant, with significant growth in each evaluation date, at an exponential rate of $1.7 \mathrm{~cm} \mathrm{~d}^{-1}$ (Figure 10A). This is an indicator of the high adaptability of this forage species under drought [31,32]. Similar behavior was observed with grass development during 2013, with an exponential growth rate of $1.5 \mathrm{~cm} \mathrm{~d}^{-1}$ (Figure 10B). The height of the plant was significantly major in both dosages of hydrogel and consequently the dry matter weight too.
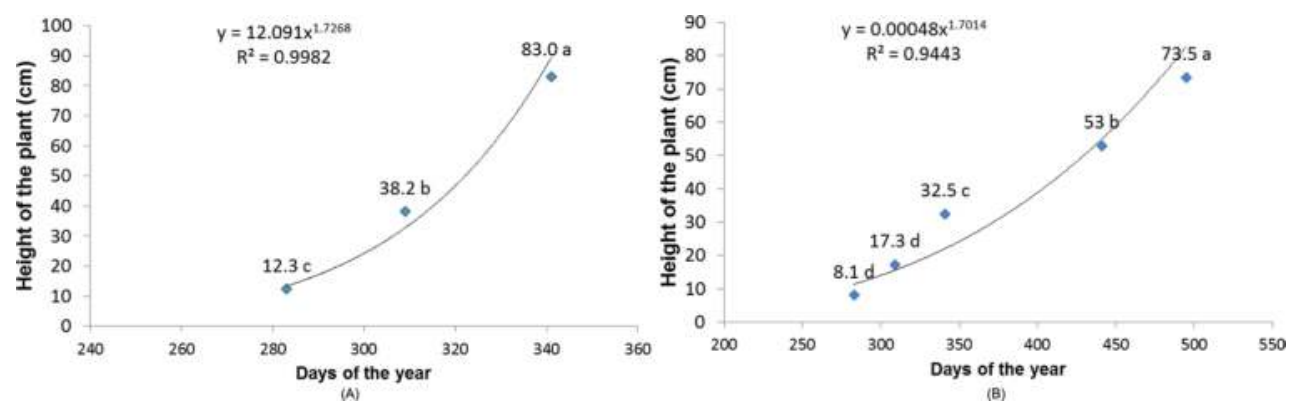

Figure 10. Growth of buffel grass in rainwater capturing watersheds, at different evaluation times during 2012 (A) and 2013 (B). 


\begin{tabular}{|c|c|c|c|c|}
\hline Hydrogel doses & $\begin{array}{l}\text { Soil moisture } \\
\text { content }(\%)\end{array}$ & $\begin{array}{l}\text { Photosynthesis } \\
\left(\mu \mathrm{mol} \mathrm{m} \mathrm{m}^{-2} \mathrm{~s}^{-1}\right)\end{array}$ & $\begin{array}{l}\text { Conductance } \\
\left(\mathrm{mol} \mathrm{m}^{-2} \mathrm{~s}^{-1}\right)\end{array}$ & $\begin{array}{l}\text { Transpiration } \\
\left(\mathrm{mmol} \mathrm{H}_{2} \mathrm{O} \mathrm{m}^{-2} \mathrm{~s}^{-1}\right)\end{array}$ \\
\hline 0 & $16.4 \mathrm{~b}$ & $3.72 b$ & $0.0055 b$ & $0.214 \mathrm{c}$ \\
\hline 5 & $19.5 a$ & $3.82 \mathrm{~b}$ & $0.0089 a$ & $0.227 \mathrm{bc}$ \\
\hline 10 & $17.2 \mathrm{ab}$ & $4.05 \mathrm{ab}$ & $0.0066 \mathrm{ab}$ & $0.255 b$ \\
\hline 15 & $18.4 \mathrm{a}$ & $6.67 a$ & $0.0099 a$ & $0.382 \mathrm{a}$ \\
\hline
\end{tabular}

Tukey test $(P \leq 0.05)$. Figures with same letters within the same column are not statistically different.

Table 1. Effect of hydrogel on photosynthetic activity and other physiological variables on buffel grass (Cenchrus ciliiaris L.).

Development buffel grass is dependent on the soil water content, but is tolerant to drought stress [33]. In this sense, hydrogel showed better effects enhancing plant growth and increasing biomass production in other crops as beet (Beta vulgaris var. cycla) [34] and tomato (Lycopersicon esculentum Mill) [35].

\subsection{Photosynthetic activity and transpiration}

Photosynthetic activity and transpiration of the plant were measured by the $\mathrm{C}_{2}$ and $\mathrm{H}_{2} 0$ flow, respectively using the infrared gas analysis (IRGA) model LICOR-6400. The photosynthesis was significantly higher in the dosages of $15 \mathrm{~kg} \mathrm{ha}^{-1}$ of hydrogel at a rate of assimilation 6.67 $\mathrm{mmol} \mathrm{CO} \mathrm{m}^{-2} \mathrm{~s}^{-1}$, compared to the assimilation rate obtained when the product was applied to 5 or $10 \mathrm{~kg} \mathrm{ha}^{-1}$ or not applied, with values of 3.7, 3.8, and 4, respectively. Higher photosynthesis rates were associated with greater conductance and transpiration, and vice versa (Table 1). Thus, the presence of moisture in the soil promotes plant photosynthetic activity, while water deficits decrease it [36]. The photosynthetic activity of the grass was strongly influenced by the condition of soil moisture; this was identified on November 6, 2013, with an average soil moisture of $18.4 \%$ when the hydrogel was applied, with no statistical differences between the dosages. All this indicates that the moisture content in the soil is influenced by hydrogel (Table 1).

\subsection{Another practice of retention of soil moisture}

The aim of this study was to evaluate different soil moisture retention practices in the survival and growing grass (Boutelova curtipendula and Chloris gayana) in areas of productive reconversion. Dosages of stubble of dry corn $\left(0\right.$ and $\left.10 t \mathrm{tha}^{-1}\right)$, and hydrogel dosages $(0,10$ and $20 \mathrm{~kg} \mathrm{ha}^{-1}$ ) were used, including two species of grasses B. curtipendula (native grass) and C. gayana (introduced grass) [37].

\subsection{Seed germination}

A number of seeds germinated B. curtipendula was to a rate significantly higher than the introduced species C. gayana. Germination started 2 days after sowing at a rate of germination in a logarithmic function (Figure 11). The latency mechanism of the native species is inherent to its 


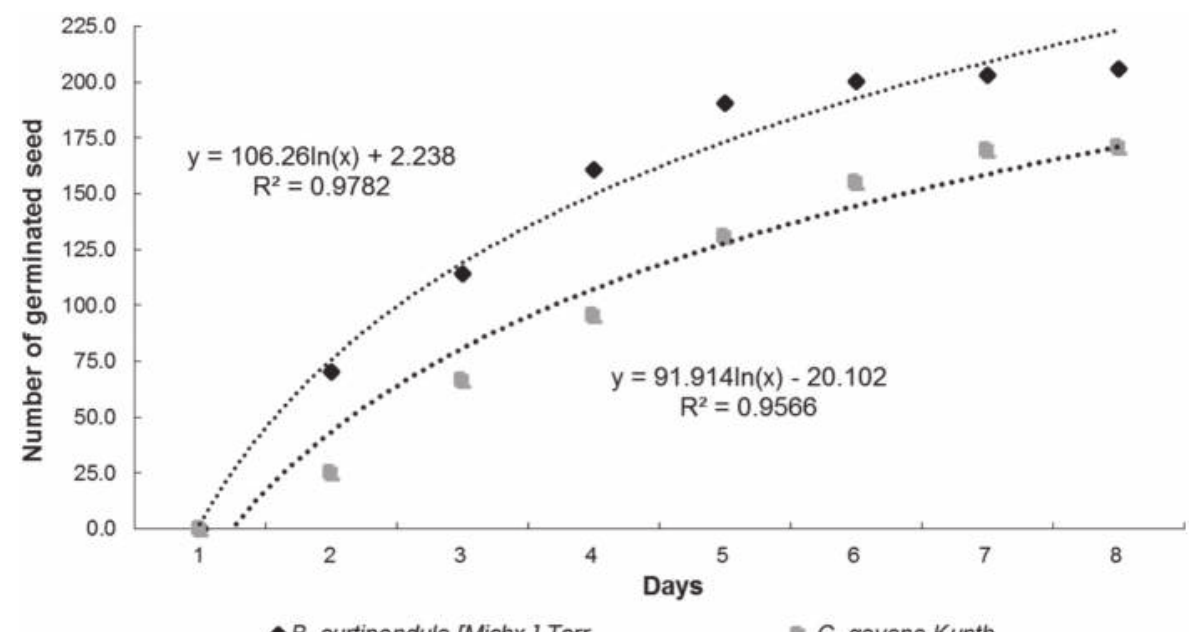

Figure 11. Germination rate in pastures B. curtipendula [Michx.] Torr. and C. gayana Kunth; discontinuous points represent the trend of the line.

high germination capacity [38]; even a high percentage of germination of exotic species is not enough for the success in potential production. Additionally, one characteristic of grass B. curtipendula was the high germination rate in the early stages of growth [39].

\subsection{Moisture content}

The moisture content was higher when applying hydrogel at 15 days after the rain (DAR) at each soil depth evaluated. This effect disappeared after evaluation dates without significance among hydrogel treatments for both soil depths (Figure 12). Hydrogel offers better water
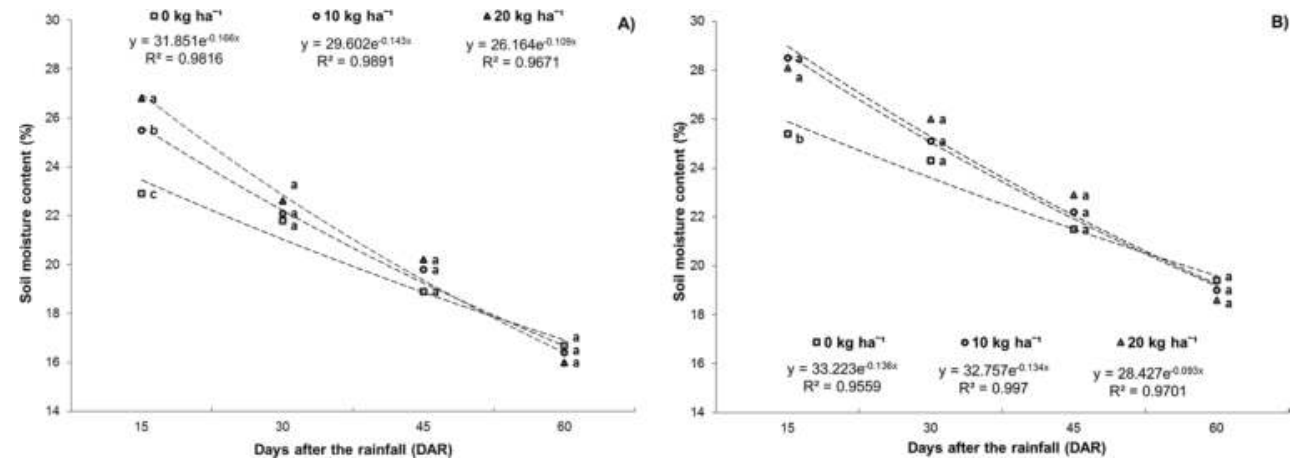

Figure 12. Moisture reduction at $30 \mathrm{~cm}$ (A) and $45 \mathrm{~cm}$ (B) depth of soil in different hydrogel contents and different sampling dates: $15,30,45$, and 60 days after the rainfall. Tukey test $(P \leq 0.05)$. Different letters over the same line means differences among treatments. 

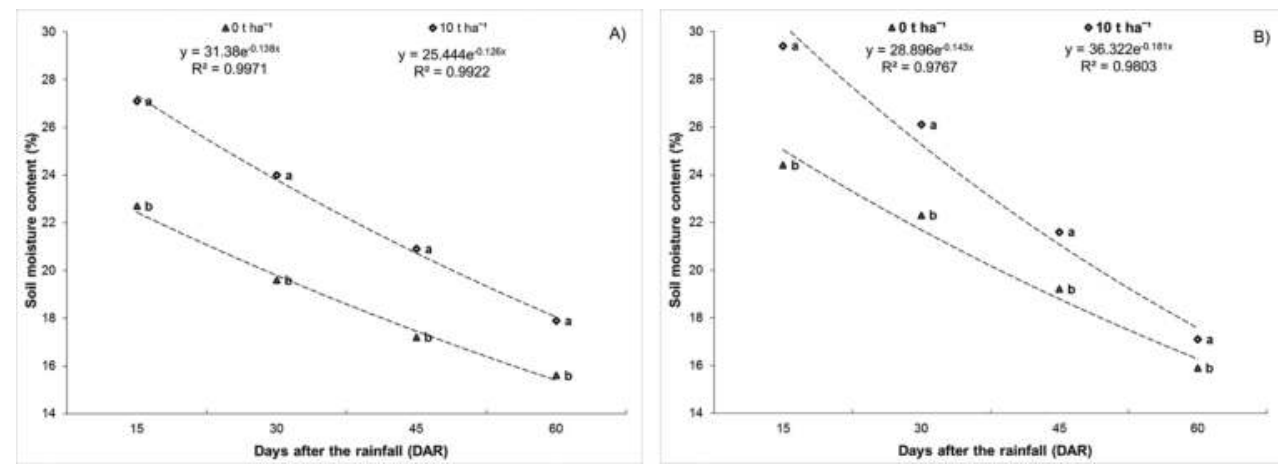

Figure 13. Moisture reduction at $30 \mathrm{~cm}$ (A) and $45 \mathrm{~cm}$ (B) depth of soil associated with dry corn stubble doses and different sampling dates: 15,30 , and 45 and 60 days after rainfall. Tukey test $(P \leq 0.05)$. Different letters over the same line means differences among treatments.

release properties when combined with soil and retains larger amounts of water, either under instant or prolonged irrigation conditions, and maintains moisture at a higher value in crops [40]. These results differ from those found for other research studies [41], who found higher soil moisture content when applying hydrogel to a soil depth of $0-15 \mathrm{~cm}$, in relation to the control, throughout the rice growing season. Also the hydrogel improves the rapidly available water capacity (RAWC) of soils; although the effectiveness of the gel in improving soil water retention varies for different soil types [42].

Moisture retention characteristics of the hydrogel are inherent to constant hydration, a condition that was not present at the study site due to low rainfall; in other hand, the occurrence of precipitation for arid and semi-arid zones is not homogeneous, and highly variable in time. Regarding the application of dry corn stubble, the moisture content at both evaluated depths remained higher at each evaluation date than the harvest residue was not added (Figure 13). The useful moisture range for this type of soil is $18 \%$, since the field capacity (FC) is $33 \%$ and the permanent wilting point (PWP) is $15 \%$. In the treatment without stubble application reached values of $16 \%$ always, very close to PWP. Application of dry corn stubble maintained soil moisture content higher than $18 \%$ always, with a lower rate of humidification than the treatment without stubble an average of both soil depths (30 and $40 \mathrm{~cm}$ ); the treatment with corn stubble obtained 3.7 and 3.1\% more moisture content than the control at $30 \mathrm{~cm}$ and $45 \mathrm{~cm}$ depth, respectively.

\subsection{Percentage of survival}

The percentage of survival of the grass was significantly different from the species (Figure 14). Both B. curtipendula and C. gayana had a survival rate greater than $84 \%$, 6 weeks after transplant; however, C. gayana had a higher percentage with $87 \%$ compared to the native grass, which reported $84.1 \%$. Agree Ref. [43], the grazing transplant method represents an effective technique to increase the percentage of survival in grassland areas. The practice of planting 


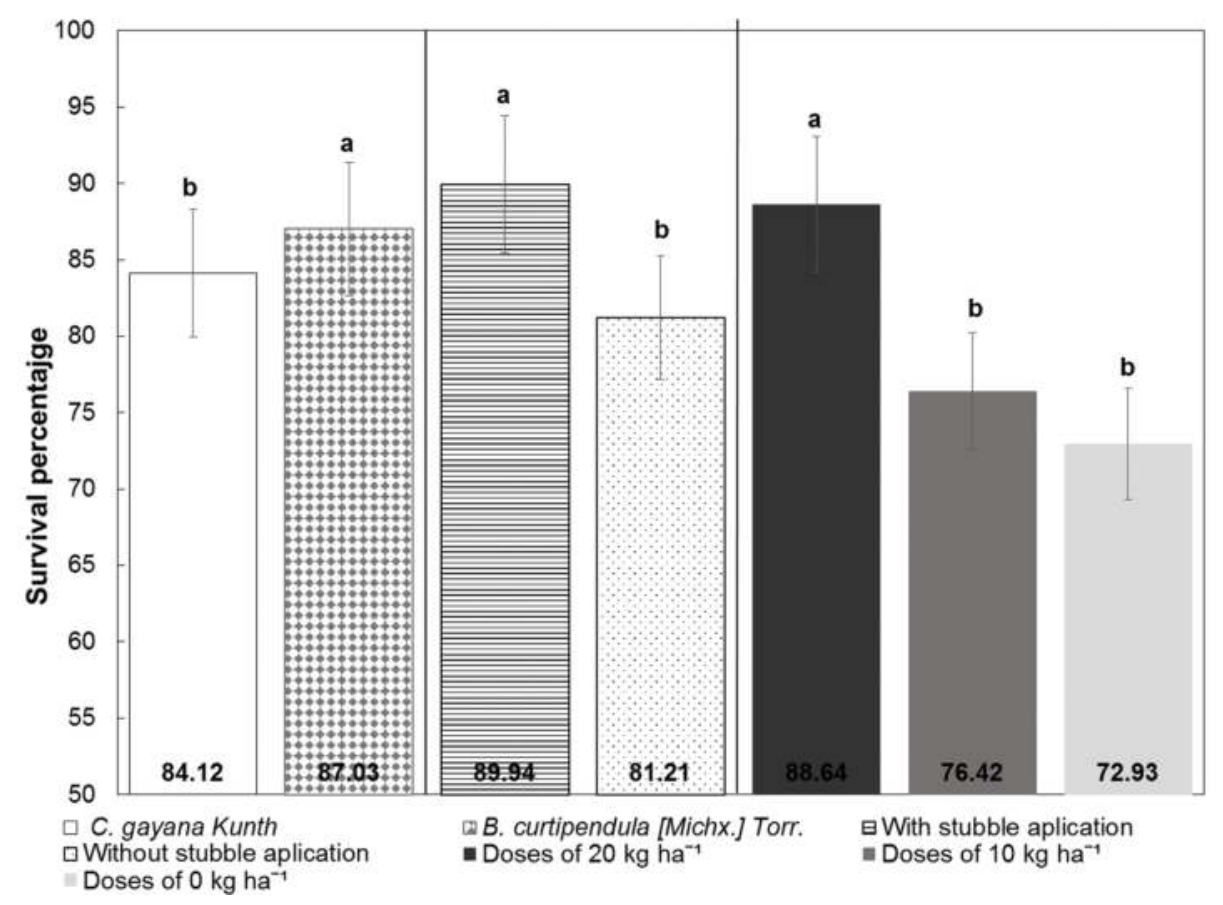

Figure 14. Percentage of survival by grass species with application of $10 \mathrm{t} \mathrm{ha}^{-1}$ of stubble and without application of stubble; application of hydrogel at doses of $20 \mathrm{~kg} \mathrm{ha}^{-1}, 10 \mathrm{~kg} \mathrm{ha}^{-1}$, and $0 \mathrm{~kg} \mathrm{ha}^{-1}$. Vertical bars represent the standard deviation \pm . Columns with equal letters are not statistically different $(P \leq 0.05)$.

seeds of forage grasses improves the productivity of livestock areas in the arid and semi-arid zones. Studies have shown that the practice of planting directly has success of only $10 \%$; in other cases, the probability of success is $50 \%$. In contrast, for this study, values higher than $95 \%$ of live plants ([number of deaths plants/number of live plants] $\times 100$, after 45 days of the transplanted) in buffel grass was shown using the transplant method, considered a highly effective method of planting even in soils with limited natural fertility [43]. In addition, it has been reported that, for experimental procedures, the transplantation technique guarantees the obtaining of reliable information by reducing the experimental error to acceptable values. The percentage of planting buffel grass varied from 74 to $99 \%$, without significant differences between plant species, which had an average of $90 \%$ of establishment [44].

The percentage of survival of the grasses when applying hydrogel was significantly higher, compared to no application; $89.3 \%$ and $76.4 \%$ of survival were found for the doses 20 and $10 \mathrm{~kg} \mathrm{ha}^{-1}$, respectively, without statistical difference between them. Similar results showed treatments with stubble application, the percentage of survival was significantly higher, when applying corn stubble $(89.9 \%)$, with respect to that when it was not applied $(81.2 \%)$ (Figure 13). Similar results have been reported, when vegetation cover is not applied, the percentage of forest species survival is significantly reduced to $66.7 \%$ [45]. 


\begin{tabular}{|c|c|c|c|c|c|c|c|c|}
\hline \multirow{2}{*}{$\begin{array}{l}\text { Dose of } \\
\text { retainer of } \\
\text { soil water }\end{array}$} & \multicolumn{2}{|c|}{ Number of tillers } & \multicolumn{2}{|c|}{ Plant height (cm) } & \multicolumn{2}{|l|}{ CCI } & \multicolumn{2}{|c|}{ Vigor (0-5) } \\
\hline & BC & CG & BC & CG & BC & CG & BC & CG \\
\hline \multicolumn{9}{|l|}{ Hydrogel } \\
\hline $0 \mathrm{~kg} \mathrm{ha}^{-1}$ & $\begin{array}{l}5.6 \mathrm{a} \\
\pm 1.0\end{array}$ & $\begin{array}{l}3.5 \mathrm{a} \\
\pm 0.8\end{array}$ & $\begin{array}{l}26.9 \mathrm{a} \\
\pm 4.8\end{array}$ & $\begin{array}{l}33.1 \mathrm{a} \\
\pm 4.8\end{array}$ & $\begin{array}{l}98.6 \mathrm{a} \\
\pm 5.3\end{array}$ & $\begin{array}{l}114.3 \mathrm{a} \\
\pm 5.1\end{array}$ & $3.7 \mathrm{a} \pm 0.5$ & $\begin{array}{l}4.1 \mathrm{a} \\
\pm 0.6\end{array}$ \\
\hline $10 \mathrm{~kg} \mathrm{ha}^{-1}$ & $\begin{array}{l}5.7 \mathrm{a} \\
\pm 0.9\end{array}$ & $\begin{array}{l}3.6 \mathrm{a} \\
\pm 0.9\end{array}$ & $\begin{array}{l}27.7 a \\
\pm 5.2\end{array}$ & $\begin{array}{l}34.9 \mathrm{a} \\
\pm 4.6\end{array}$ & $\begin{array}{l}95.9 \mathrm{a} \\
\pm 4.7\end{array}$ & $\begin{array}{l}113.2 \mathrm{a} \\
\pm 5.7\end{array}$ & $\begin{array}{l}3.3 \mathrm{a} \\
\pm 0.7\end{array}$ & $\begin{array}{l}4.5 \mathrm{a} \\
\pm 0.7\end{array}$ \\
\hline $20 \mathrm{~kg} \mathrm{ha}^{-1}$ & $\begin{array}{l}5.9 \mathrm{a} \\
\pm 1.1\end{array}$ & $\begin{array}{l}3.2 \mathrm{a} \\
\pm 0.9\end{array}$ & $\begin{array}{l}27.2 \mathrm{a} \\
\pm 4.3\end{array}$ & $\begin{array}{l}32.6 \mathrm{a} \\
\pm 3.6\end{array}$ & $\begin{array}{l}97.8 \mathrm{a} \\
\pm 4.3\end{array}$ & $\begin{array}{l}109.8 \mathrm{a} \\
\pm 6.2\end{array}$ & $\begin{array}{l}3.5 \mathrm{a} \\
\pm 0.4\end{array}$ & $\begin{array}{l}4.3 \mathrm{a} \\
\pm 0.5\end{array}$ \\
\hline \multicolumn{9}{|c|}{ Dry stubble coverage } \\
\hline 0 tha $^{-1}$ & $\begin{array}{l}4.4 \mathrm{~b} \\
\pm 0.9\end{array}$ & $\begin{array}{l}3.0 \mathrm{~b} \\
\pm 0.7\end{array}$ & $\begin{array}{l}22.6 b \\
\pm 2.6\end{array}$ & $\begin{array}{l}29.5 b \\
\pm 3.1\end{array}$ & $\begin{array}{l}84.4 \mathrm{~b} \\
\pm 6.4\end{array}$ & $\begin{array}{l}107.8 \mathrm{~b} \\
\pm 6.7\end{array}$ & $4.0 \pm 0.4^{b}$ & $\begin{array}{l}3.8 \mathrm{~b} \\
\pm 0.5\end{array}$ \\
\hline $10 \mathrm{t} \mathrm{ha}^{-1}$ & $\begin{array}{l}7.1 \mathrm{a} \\
\pm 0.8\end{array}$ & $\begin{array}{l}3.8 \mathrm{a} \\
\pm 0.8\end{array}$ & $\begin{array}{l}31.9 \mathrm{a} \\
\pm 3.3\end{array}$ & $\begin{array}{l}37.2 \mathrm{a} \\
\pm 3.4\end{array}$ & $\begin{array}{l}98.5 \mathrm{a} \\
\pm 5.9\end{array}$ & $\begin{array}{l}121.5 \mathrm{a} \\
\pm 7.4\end{array}$ & $\begin{array}{l}2.9 a \\
\pm 0.7\end{array}$ & $\begin{array}{l}4.7 \mathrm{a} \\
\pm 0.3\end{array}$ \\
\hline
\end{tabular}

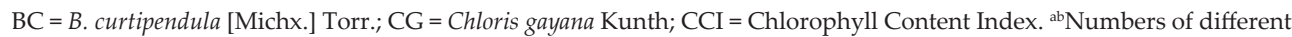
letter into the same column, and into each variation factor (hydrogel and dry stubble coverage) are statistical different $(P<0.05)$.

Table 2. Growing variables in two grass species in different hydrogel doses and dry stubble coverage.

\subsection{Growth and plant development}

Dry stubble coverage at doses $10 \mathrm{tha}^{-1}$ significantly influenced the plant height, number of tillers, and chlorophyll index and plant vigor of the grass species during different evaluation dates (Table 2). The introduced grass was superior in all variables with respect to the native grass. Studies with stubble use showed effects with the addition of mulch or peat cover on peanut cultivation, significantly influencing some agronomic attributes of crop growth and yield [46].

Plant growth, forage yield of the guinea grass was increased when straw in saline soils was applied [47]. Also Ref. [48] identified that the incorporation of mulch to the soil for establishment of grasses, had superior results, related to maximized vegetation of grasses and greater amount of biomass, regarding the treatments without addition of straw.

\subsection{Biomass production}

The effect of stubble was related to higher and evenly distributed soil moisture content, which allowed a better yield of biomass in each evaluation. In contrast, the hydrogel showed only statistical differences at 30 days after the transplantation when applying 10 or 20 ton ha ${ }^{-1}$, without statistical difference in the first dose with the control, in the case of B. curtipendula. In the two subsequent evaluations, the effect was no longer shown, which may be related to the dilution effect identified in soil moisture content. The introduced grass was always higher in area and radicular biomass for the three evaluations performed (Table 3). 


\begin{tabular}{|c|c|c|c|c|c|c|}
\hline \multirow{3}{*}{$\begin{array}{l}\text { Dose of retaine } \\
\text { of soil water }\end{array}$} & \multicolumn{6}{|c|}{ Dry weight of biomass (g) } \\
\hline & \multicolumn{2}{|l|}{30 DAT } & \multicolumn{2}{|c|}{45 DAT } & \multicolumn{2}{|c|}{60 DAT } \\
\hline & $\mathrm{BC}$ & CG & $\mathrm{BC}$ & CG & $\mathrm{BC}$ & CG \\
\hline \multicolumn{7}{|l|}{ Hydrogel } \\
\hline $0 \mathrm{~kg} \mathrm{ha}^{-1}$ & $\begin{array}{l}11.0 \mathrm{~b} \\
\pm 1.7\end{array}$ & $\begin{array}{l}17.5 \mathrm{~b} \\
\pm 3.3\end{array}$ & $\begin{array}{l}45.1 \mathrm{a} \\
\pm 6.0\end{array}$ & $\begin{array}{l}57.9 \mathrm{a} \\
\pm 5.5\end{array}$ & $\begin{array}{l}53.3 \mathrm{a} \\
\pm 7.1\end{array}$ & $\begin{array}{l}68.0 \mathrm{a} \\
\pm 7.0\end{array}$ \\
\hline $10 \mathrm{~kg} \mathrm{ha}^{-1}$ & $\begin{array}{l}13.3 \mathrm{ab} \\
\pm 2.2\end{array}$ & $\begin{array}{l}24.3 \mathrm{a} \\
\pm 4.1\end{array}$ & $\begin{array}{l}42.8 \mathrm{a} \\
\pm 5.9\end{array}$ & $\begin{array}{l}56.0 \mathrm{a} \\
\pm 5.8\end{array}$ & $\begin{array}{l}51.5 \mathrm{a} \\
\pm 6.3\end{array}$ & $\begin{array}{l}66.8 \mathrm{a} \\
\pm 7.6\end{array}$ \\
\hline $20 \mathrm{~kg} \mathrm{ha}^{-1}$ & $\begin{array}{l}14.7 \mathrm{a} \\
\pm 2.0\end{array}$ & $\begin{array}{l}25.6 \mathrm{a} \\
\pm 4.9\end{array}$ & $\begin{array}{l}44.7 \mathrm{a} \\
\pm 5.3\end{array}$ & $\begin{array}{l}56.9 \mathrm{a} \\
\pm 4.2\end{array}$ & $\begin{array}{l}51.6 \mathrm{a} \\
\pm 6.2\end{array}$ & $\begin{array}{l}67.7 \mathrm{a} \\
\pm 5.8\end{array}$ \\
\hline \multicolumn{7}{|l|}{ Dry stubble corn } \\
\hline 0 tha $^{-1}$ & $\begin{array}{l}12.3 \mathrm{~b} \\
\pm 2.1\end{array}$ & $\begin{array}{l}20.4 \mathrm{~b} \\
\pm 1.6\end{array}$ & $\begin{array}{l}39.8 \mathrm{~b} \\
\pm 3.3\end{array}$ & $\begin{array}{l}52.3 b \\
\pm 2.7\end{array}$ & $\begin{array}{l}47.2 \mathrm{~b} \\
\pm 4.4\end{array}$ & $\begin{array}{l}61.1 \mathrm{~b} \\
\pm 2.8\end{array}$ \\
\hline $10 \mathrm{tha}^{-1}$ & $\begin{array}{l}16.1 \mathrm{a} \\
\pm 0.9\end{array}$ & $\begin{array}{l}28.6 \mathrm{a} \\
\pm 1.9\end{array}$ & $\begin{array}{l}48.8 \mathrm{a} \\
\pm 3.9\end{array}$ & $\begin{array}{l}61.1 \mathrm{a} \\
\pm 2.8\end{array}$ & $\begin{array}{l}57.2 \mathrm{a} \\
\pm 4.5\end{array}$ & $\begin{array}{l}73.2 \mathrm{a} \\
\pm 3.2\end{array}$ \\
\hline
\end{tabular}

$\mathrm{BC}=$ B. curtipendula [Michx.] Torr.; CG $=$ Chloris gayana Kunth DAT $=$ Days after of the transplant. ${ }^{\text {ab Numbers of different }}$ letter into the same column, and into each variation factor (hydrogel and dry stubble coverage) are statistical different $(P<0.05)$.

Table 3. Biomass production in two grass species to different hydrogel and dry stubble corn dosages.

\section{General conclusions}

Ecological zoning through indicators such as aridity, drought, type of vegetation, and type of soil use is often an effective tool in a more systematic and targeted application of technologies for a better management of natural resources, according to the potential of each small region.

Water is the most limited natural resource and therefore of major importance to be considered in development plans in arid lands to optimize the use of this resource and avoid environmental deterioration such as soil degradation, turning productive areas into unproductive ones.

An integrated system, such as use of water stress tolerant plant species, rainwater harvesting, and soil moisture retention practices, like the experiences and results shown in this chapter, may be the useful tools for the productive reconversion of areas degraded in arid lands.

Exploration and integrating technological practices focused on promoting effective management of natural resources in ecosystems and agro-ecosystems, is a current an issue where the main constraint is water.

\section{Acknowledgements}

We want to thank to Chapingo Autonomous University for financial support to carry out the research related to the topic of the mitigation of degraded soils in arid zones, as well as to the National Institute of Agricultural Livestock and Forestry Research for their collaborations in this project. 


\section{Author details}

Aurelio Pedroza-Sandoval ${ }^{1}$, Ricardo Trejo-Calzada ${ }^{1 *}$, Ignacio Sánchez-Cohen²,

Luis G. Yáñez-Chávez ${ }^{1}$, Adriana Cruz-Martínez ${ }^{1}$ and Uriel Figueroa-Viramontes ${ }^{2}$

*Address all correspondence to: rtrejo@chapingo.uruza.edu.mx

1 Chapingo Autonomous University, Bermejillo, Durango, Mexico

2 National Institute of Agricultural Livestock and Forestry Research, Ciudad de México, Mexico

\section{References}

[1] ONU. La población mundial alcanzará los 9.6 mil millones en 40 años [Internet]. 2014. Available from: http://actualidad.rt.com/actualidad/view/97314-poblacion-mundial-crecimiento-onu [Accessed: 6 March 2016]

[2] Cruse MR. Agriculture: Is climate change a serious issue? Revista Agrociencia Uruguay. Special Issue. 2012; Sept.:9-19

[3] Al-Kaisi M, Elmore RW, Guzman JG, Hanna HM, Hart CE, Helmers MJ, Hodgson EW, Lenssen AW, Mallarino AP, Robertson AE, Sawyer JE. Drought impact on crop production and the soil environment: 2012 experiences from Iowa. Journal of Soil and Water Conservation. 2012;68(1):19-24

[4] UNCCD. Segunda Conferencia Científica de la CLD; Aspectos económicos de la desertificación, la degradación de las tierras y la sequía: Metodologías y análisis para la toma de decisiones [Internet]. 2013. Available from: http://2sc.unccd.int/es/inicio [Accessed: 14 March 2014]

[5] IFPRI. Informe de Políticas Alimentarias Mundiales 2011. Washington, D.C.: IFPRI; 2012. p. 126. DOI: $10.2499 / 9780896295513$

[6] Velásquez MA, Medina García G, Sánchez Cohen I, Klauidia Oleschko L, Ruiz Corral JA, Korvin G. Spatial variability of the Hurst exponent for the daily scale rainfall series in the state of Zacatecas Mexico. Journal of Applied Meteorology and Climatology. 2013;52:2771-2780. DOI: 10.1175/JAMC-D-13-0136.1

[7] González MG. Las zonas áridas y semiáridas de México, y su vegetación. Primera ed. SEMARNAT-INECC. Impreso en México; 2012. p. 194

[8] CNA. Programa Hidráulico de Gran Visión 2001-2025. Torreón, Coahuila: Gerencia Regional de las Cuencas Centrales del Norte; 2001

[9] CNA. Atlas Digital del Agua (2010). Contraste Regional Entre el Desarrollo y la Disponibilidad del Agua [Internet]. 2008. Available from: http://www.conagua.gob.mx/ atlas/atlas.html?seccion=0<mapa=8 [Accessed: 16 October 2014] 
[10] Díaz PG, Cortina CMF, Rodríguez PL. Potencial agro-productivo de cada hectárea de la superficie territorial del estado de Veracruz. Décima cuarta Reunión científica-tecnológica forestal y agropecuaria; 2001

[11] Barón WVS. Zonificación agroclimática para el establecimiento de sistemas silvopastoriles con Paulownia elongata [thesis]. Chapingo, México: Universidad Autónoma Chapingo; 2013

[12] FAO. Agua para la alimentación. Agua para la vida. Una evaluación exhaustiva de la gestión del agua en la agricultura. Washington, D.C.; 2007. p. 57 [Internet]. 2007. Available from: http:www.academia.edu/30158519/Agua_para_la_alimentación_Agua_ para_la_vida [Accessed: 17 June 2015]

[13] Yáñez CLG, Pedroza SA, Martínez SM, Sánchez CI, Echavarría CJG, Velásquez VMA, López SA. Caracterización fisiográfica y regionalización de la Cuenca media río NazasAguanaval. Revista Chapingo Serie Zonas Áridas. 2017 [in progress]

[14] Pedroza SA. El déficit hídrico en las plantas. Principios y técnicas de manejo. Bermejillo, Dgo: Universidad Autónoma Chapingo, Unidad Regional Universitaria de Zonas Áridas; $1995.162 \mathrm{p}$

[15] INEGI (Instituto Nacional de Estadística, Geografía, e Informática). Descarga de mapas digitales de la República Mexicana [Internet]. 2015. Available from: http://www.inegi. org.mx/geo/contenidos/recnat/default.aspx [Accessed: 17 May 2016]

[16] ESRI. ArcGIS 10.1; also contains ESRI Data and Maps for ArcGIS. Redlands, CA; 2012

[17] Stretta EJ, Mosiño PA. Distribución de las zonas áridas de la república según un nuevo índice de aridez derivado del de Emberger. Ingeniería Hidráulica en México. 1963;16: $40-47$

[18] SMN (Servicio Meteorológico Nacional). Normales climatológicas. México D.F.: Comisión Nacional del Agua; 2010

[19] Etchevers BJD, Gómez DJD, Monterroso RAI, Tinoco RJA. Formulación de indicadores para evaluar y monitorear la desertificación en México. Secretaría de Medio Ambiente y Recursos Naturales, Instituto de Ecología, Colegio de Posgraduados, Universidad Autónoma Chapingo; 2013. 155 p

[20] Velasco I, Reyes O. Caracterización hídrica del Estado de Sinaloa, mediante el índice de aridez y el régimen de aridez. Instituto Mexicano de Tecnología del Agua. Resumen Núm.028 del Congreso de Ciencias Ambientales. Universidad Nacional Autónoma del Estado de México. Mesa de Recursos Naturales [Internet]. 2007. Available from: www. uaemex.mx/Red_Ambientales/docs/congresos/.../RN028.doc [Accessed: 15 April 2015]

[21] Stankey G, Cole D, Lucas R, Petersen M, Frissell S. The limit of acceptable change, system for wilderness planning. General Technical Report INT-176. Ogden, UT, USA: U.S. Department of Agriculture. Forest Service. Intermountain Forest and Range Experiment Station; 1985. p. 37 
[22] FAO. Secuestro de carbono en tierras áridas. Roma: Organización de las Naciones Unidas para la Agricultura y la Alimentación; 2007. p 138

[23] UACh. Actualización de la delimitación de las zonas áridas, semiáridas y subhúmedas de México a escala regional. Chapingo, México: Departamento de Suelos, Universidad Autónoma Chapingo; 2011

[24] Cruz Martínez A, Pedroza Sandoval A, Trejo Calzada R, Sánchez Cohen I, Samaniego Gaxiola JA, Cantú Brito JE. Alternatives and decision-making in natural resource management in degraded dryland areas. Revista Chapingo Serie Zonas Áridas. 2015;14(1):51-60. DOI: $10.5154 /$ r. rchsza.2014.12.004

[25] Sánchez Cohen I, Estrada Avalos J, Cueto Wong J. Toma de decisiones en grupo para el manejo de los recursos naturales. Métodos de análisis y criterios de selección. Folleto Científico No. 24. Gómez Palacio, Dgo: INIFAP CENID RASPA; 2008. 73 p

[26] Heilman P, Stone J, Sánchez Cohen I, Macías Rodríguez H, Mann RS. Working smarter: Research and decision support systems in Mexican agriculture. In: Richardson C, Baez D, Tiscareño M, editors. Modeling and Remote Sensing Applied to Agriculture. U.S. and Mexico; 2005. pp. 211-236

[27] Cruz Martínez A, Pedroza Sandoval A, Trejo Calzada R, Sánchez Cohen I, Samaniego Gaxiola JA, Hernández Salgado R. Captación de agua de lluvia y retención de humedad edáfica en el establecimiento de buffel (Cenchrus ciliaris 1). Revista Mexicana de Ciencias Pecuarias. 2016;7(2):159-172

[28] INIFAP. Red de Estaciones Agroclimáticas. Secretaría de Agricultura Ganadería y Pesca [Internet]. 2014. Available from: http://clima.inifap.gob.mx/lnmysr [Accessed: 14 May 2014]

[29] Idrobo H, Díaz AM, Ortiz JE. Comportamiento del hidrogel en suelos arenosos. Ingeniería de los recursos naturales y del ambiente. 2010;19:27-31

[30] Rojas GB, Ramírez M, Aguilera R, Prin JL, Torres C. Los hidrogeles poliméricos como potenciales reservorios de agua y su aplicación en la germinación de semillas de tomate en diferentes tipos de suelos. Revista Iberoamericana de Polímeros. 2006;7(3):199-210

[31] Beltrán LS, Loredo OC. Reconversión de áreas agrícolas marginales a praderas de pasto buffel. Folleto Técnico para Productores. INIFAP; 2002

[32] Burquez A. El zacate buffel: transformación ecológica y social. CONABIO. Biodiversitas. 2007;74:8-12

[33] Alcalá GC. Guía práctica para el establecimiento, manejo y utilización del zacate buffel. Patronato del Centro de Investigaciones Pecuarias del Estado de Sonora, A. C. [Internet]. 1995. Available from: http://www.patrocipes.org.mx/publicaciones/pastizales/p95009. php [Accessed: 15 April 2014]

[34] Gutiérrez CIJ, Sánchez CI, Cueto WJ, Trucios CR, Trejo CR, Flores HA. Efecto del polímero Aquasorb ${ }^{\circledR}$ en la capacidad de retención de humedad del suelo y su efecto en el rendimiento de la acelga (Beta vulgaris var. cycla). Revista Chapingo Serie Zonas Áridas. 2008;7(1):66-72 
[35] Rivera HC, Baeza AA, Chavarriaga MW. Efecto de un retenedor de agua y dosis crecientes de fertilizantes foliares sobre la producción de tomate chonto y larga vida bajo cubierta plástica. Agroclear Agron. 2007;15:1-17

[36] Tezara WM, Driscoll SD, Lawlor DW. Water stress inhibits plant photosynthesis by decreasing coupling factor and ATP. Nature. 1999;1401:914-917

[37] Yáñez CLG, Pedroza SA, Martínez SM, Sánchez CI, Echavarría CJG, Velásquez VMA, López SA. Retención de humedad edáfica en la sobrevivencia y crecimiento de dos especies de pastos Bouteloua curtipendula [Michx.] Torr. y Chloris gayana Kunth en Durango, México. Revista Mexicana de Ciencias Pecuarias. 2017 [in progress]

[38] Carrillo SSM, Arredondo MT, Huber-Sannwald E, Flores RJ. Comparación en la germinación de semillas y crecimiento de plántulas entre gramíneas nativas y exóticas del pastizal semiárido. Revista Mexicana de Ciencias Pecuarias. 2009;47(3):299-312

[39] Esqueda CMH, Melgoza CA, Sosa CM, Carrilo RR, Jiménez CJ. Emergencia y sobrevivencia de gramíneas con diferentes secuencias de humedad-sequía en tres tipos de suelo. Revista Mexicana de Ciencias Pecuarias. 2012;43(1):101-115

[40] Barón CA, Barrera RIX, Boada ELF, Rodríguez NG. Evaluación de hidrogeles para aplicaciones agroforestales. Revista Ingeniería e Investigación. 2007;27:35-44

[41] Rehman R, Ahmad R, Safdar M. Effect of hydrogel on the performance of aerobic rice sown under different techniques. Plant, Soil and Environment. 2011;57:321-325

[42] Narjary B, Aggarwal P, Singh A, Chakraborty D, Singh R. Water availability in different soils in relation to hydrogel application. Geoderma. 2012;187:94-101

[43] Gómez MS, González DJR, Aguilar PD. Evaluación de híbridos experimentales de zacate buffel en suelo arcilloso del norte centro de México. Memorias del VI Congreso Internacional de Manejo de Pastizales. Durango, Dgo; 2015. 467 p

[44] González DJR, Gómez MS, López DA. El transplante garantiza establecer zacates forrajeros en suelos salinos y arcillosos. Memorias del VI Congreso Internacional de Manejo de Pastizales. Durango, Dgo; 2015. 464 p

[45] Nissen J, Ovando C. Efecto de un hidrogel humectado aplicado a las raices de nothofagus obliqua (MIRB.) OERST. Y Nothofagm dombeyi (MIRB.) OERST. durante su trasplante. Agro sur. 1999;27(2):48-58

[46] Ravisankar N, Balakrishnan M, Ambast SK, Srivastava RC, Bommayasamy N, Subramani $\mathrm{T}$. Influence of irrigation and crop residue mulching on yield and water productivity of table purpose groundnut (Arachis hypogaea) in humid tropical island. Legume Research: An International Journal. 2014;37(2):195-200. DOI: 10.5958/j.0976-0571.37.2.029

[47] Kusmiyati F, Sumarsono S, Karno K, Pangestu E. Effect of mulch and mixed cropping grass-legume at saline soil on growth, forage yield and nutritional quality of guinea grass. Journal of the Indonesian Tropical Animal Agriculture. 2013;38(1):72-78

[48] Beggy HM, Fehmi JS. Effect of surface roughness and mulch on semi-arid revegetation success, soil chemistry and soil movement. Catena. 2016;143:215-220 
